\title{
Preparedness of the Sepakung Village Disaster Risk Reduction Forum in Facing Landslide Disasters
}

\author{
Yohanes Dwi Anugrahanto ${ }^{1}$, Dewi Liesnoor Setyowati², Erni Suharini ${ }^{3}$ \\ ${ }^{1}$ Postgraduate, ${ }^{2}$ Department Geography, ${ }^{3}$ Department Geography, \\ Education Universitas Negeri Semarang, Semarang City, Indonesia. \\ Corresponding Author: Dewi Liesnoor Setyowati
}

\begin{abstract}
Sepakung Village is included in a landslideprone area in Semarang Regency, Central Java. The purpose of this study was to analyze the preparedness of the Sepakung Disaster Risk Reduction Forum. The research method used is quantitative with descriptive percentage analysis technique. The population of this study were members of the Sepakung FPRB. The sampling technique used is total sampling. Data collection techniques using questionnaires, and documentation. The results of data processing show that the knowledge of the landslide risk of the FPRB Sepakung is quite good. This is shown by the average descriptive percentage score reaching $78.409091 \%$. The experience of the Sepakung FPRB is not good with an average score of $65.0909091 \%$. The attitude of the respondent's vigilance is included in the good category with a descriptive score of the percentage reaching $85 \%$. The level of preparedness of the Sepakung FPRB is in the good category with an average score of $76.931818 \%$. This condition also illustrates the concept of an effective Disaster Resilient Village to form FPRB preparedness.
\end{abstract}

Keywords: disaster risk reduction forum, landslide, disaster, preparedness

\section{INTRODUCTION}

Sepakung Village has a Disaster Risk Reduction Forum (FPRB) which was established in 2018. This forum is tasked with handling disaster-related issues at the local level. Based on the decision of the head of the Sepakung village number 11 of 2018 the FPRB is not part of the government structure of the Sepakung Village, but the government can be involved in it along with other components of the community. The process of its formation coincided with the inauguration of Sepakung Village as a Disaster Resilient Village.

The status of Sepakung Village as a Disaster Resilient Village requires community preparedness. Here the FPRB has duties and responsibilities in this regard. Research on community preparedness in dealing with disasters is urgently needed to manage disasters in the future (Aji, 2015). The community is the main actor who directly feels the impact of the disaster, it needs to be built together with emergency response efforts to disasters (Farhi et al., 2012).

One way to address the increased risk of severe natural hazard events is to build on existing qualities within communities, to strengthen capacities that enable affected communities to better prepare for, cope with, and recover from adverse impacts (Scherzer et al., 2019). This condition of preparedness will direct residents to communities that have resilience in dealing with disasters. Resilience requires improvisation, flexibility, adaptation, and innovation to change conditions(Park et al., 2013).

Preparedness is a state of readiness to respond to disasters, crises, or other types of emergency situations (Federal Emergency Management Agency; Rañeses et al., 2018). This readiness condition can be 
identified through knowledge of disaster risk, experience in dealing with disasters, and an attitude of vigilance (Rante et al., 2012). Knowledge is the basis for citizens to act. If knowledge of disaster risk is low, it can result in low awareness of citizens about disasters.

Preparedness in dealing with landslides can be seen from the ability to recognize disasters that have the potential to occur in the residential environment, the ability to recognize signs of impending disaster, and awareness to manage a disaster-friendly living environment. (Rante et al., 2012). Community capacity is very important here in realizing preparedness. This is because preparedness requires skills that must be continuously trained.

The village that has been lined up to become a disaster-resilient village is an area prone to landslides. Landslide is the movement of slope material down and out of the slope due to the influence of gravity (Alkema et al., 2011). Landslides, the movement of masses of rock, debris or soil down slopes, are natural processes that have shaped most of the Earth's landforms. (Vasudevan \& Ramanathan, 2016). If identified from the speed of movement of landslide material slides, landslides have a faster movement compared to soil crawling, flowing soil and flowing mud (Suharini, 2009).

The combination of anthropogenic and natural factors is often the cause of landslides that take lives and property losses (Naryanto, 2011). Based on studies conducted Hasnawir (2012) in South Sulawesi shows that rainfall intensity above $50 \mathrm{~mm} /$ hour can cause shallow landslides that cause property damage including loss of human life.

Human activities that can affect the occurrence of landslides, such as illegal logging and establishing settlements in cliff areas (Mariana et al., 2019). In addition, factors that cause landslides originating from other human activities include land use and land conversion, mining on the slopes of a hill and/or highlands. (Ritohardoyo,
2016). Landslides are a major threat to various lines of human life, including settlements, infrastructure, and the natural environment in most mountainous areas in the world, (Chae et al., 2017) so we need to be careful.

The role of the FPRB in participating in shaping community preparedness is very necessary. Therefore, members of this forum must first have this preparedness. The goal is that each member can become a landslide risk reduction cadre in their respective environment. That is why it is necessary to know the Preparedness of the Sepakung Village Disaster Risk Reduction Forum in Facing Landslide Disasters.

\section{MATERIALS \& METHODS}

This research is a quantitative research using a descriptive percentage analysis technique. Quantitative approach is a research method based on the philosophy of positivism, used to examine certain populations or samples, data collection using research instruments, data analysis is quantitative/statistical, with the aim of testing predetermined hypotheses. (Sugiyono, 2017). Descriptive percentage technique was used to analyze the variables of knowledge of disaster risk, experience of dealing with disasters and attitude of vigilance. The population of this study were members of the Sepakung FPRB, totaling 11 people. The sampling technique used is total sampling. This is because the existing population is less than 30 people.

Table 1.1 Likert scale for preparedness level Likert scale for preparedness level

\begin{tabular}{|l|l|l|}
\hline No & Kriteria & Skor nilai \\
\hline 1 & Strongly Agree : SS & 4 \\
\hline 2 & Agree : S & 3 \\
\hline 3 & Disagree : TS & 2 \\
\hline 4 & Strongly Disagree: STS & 1 \\
\hline \multicolumn{2}{|c|}{ Source: Data Processing, 2021} \\
\hline
\end{tabular}

Data collection techniques in this study used questionnaires distributed to respondents and documentation. The questionnaire was used to determine the level of preparedness of the FPRB in dealing with landslides in Sepakung Village. 
The measuring instrument used is a Likert scale with 4 statements, namely strongly agree, agree, disagree and disagree.

The percentage descriptive calculation to determine the preparedness level category can be seen below:

1. Percentage of maximum score

$$
\begin{aligned}
& =4 \times 20 \times 100=8000 \\
& \frac{8000}{8000} \times 100 \%=100 \%
\end{aligned}
$$

2. Percentage of minimum score $=1 \times 20 \mathrm{x}$

$$
100=2000
$$$$
\frac{2000}{8000} \times 100 \%=25 \%
$$

3. Rentang $=100 \%-25 \%$

$$
=75 \%
$$

\begin{tabular}{|c|c|}
\hline Interval (\%) & Kriteria \\
\hline$>93,77$ & Very Good \\
\hline $68,77-93,77$ & Good \\
\hline $43,76-68,76$ & Poorly \\
\hline$\leq 25-43,75$ & Not Good \\
\hline
\end{tabular}

4. Interval Class Length $=\frac{\text { range }}{\text { Many criteria }}$

$$
=\frac{75 \%}{4}=18,75 \%
$$

There are 4 criteria to determine the level of preparedness of the Sepakung FPRB, namely very good, good, poorly, and not good.

Documentation is used to collect secondary data as supporting data. The secondary data includes the physical condition of Sepakung Village and the time of landslide occurrence in Sepakung Village.

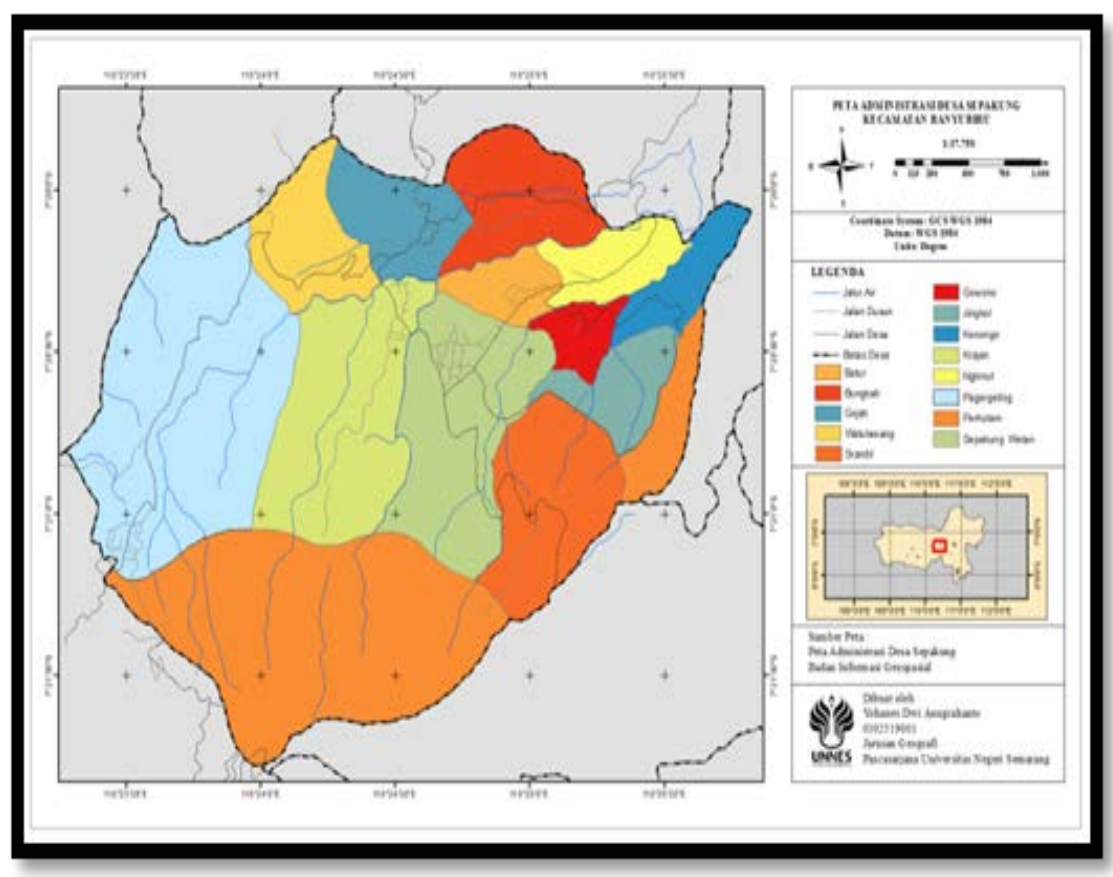

Figure 1.1 Research of Map Location Source: Data Processing, 2021

\section{RESULT AND DISCUSSION}

Sepakung Village often receives training related to disasters conducted by BPBD from both the district and provincial levels. Unfortunately, preparedness is not an absolute thing. Preparedness behavior is dynamic, sometimes it can increase or decrease. Administratively, Sepakung Village is bordered by Tegaron Village and Kemambang Village in the north, and
Kebumen Village in the east. To the south, it is bordered by Getasan Village and Magelang Regency. In the west it is bordered by Wirogomo Village. Sepakung Village is included in the administrative area of Semarang Regency.

The village of Sepakung is located in a sloping hilly area in the northern part of Mount Telomoyo, approximately at an altitude of 900-1000 meters above sea level. 
Geologically, Telomoyo Volcano is dominated by basaltic andesite lava rock types with local pyroclastic flows (Ramadhan et al., 2014). Andesite lava is one of the lava that is resistant to weathering (Dana et al., 2017). Research result Sriyono (2012) shows that Sepakung Village is in a landslide-prone area which is in zone A, zone $\mathrm{B}$, and zone $\mathrm{C}$. Zone A Sepakung Village is included in the landslide-prone area at moderate level, zones B and C include medium and low level. Most of the Sepakung Villages are included in zone C with a medium vulnerability category of 762.259 Ha. A small part of Sepakung Village is included in zone $A$ in the moderate vulnerability category of 3.16 hectares.

\section{Knowledge of Landslide Disaster Risk}

Tabel 1.2 Knowledge of Landslide Disaster Risk

\begin{tabular}{|l|l|l|l|}
\hline R & Skor & DP (\%) & Kategori \\
\hline R1 & 33 & 82,5 & Good \\
\hline R2 & 30 & 75 & Good \\
\hline R3 & 30 & 75 & Good \\
\hline R4 & 30 & 75 & Good \\
\hline R5 & 30 & 75 & Good \\
\hline R6 & 40 & 100 & Very Good \\
\hline R7 & 29 & 72,5 & Good \\
\hline R8 & 25 & 62,5 & Good \\
\hline R9 & 32 & 80 & Good \\
\hline R10 & 35 & 87,5 & Very Good \\
\hline R11 & 31 & 77,5 & Good \\
\hline Rerata & 31,363636 & 78,409091 & Good \\
\hline \multicolumn{4}{|c|}{ Source: Data Processing, 2021 } \\
\hline
\end{tabular}

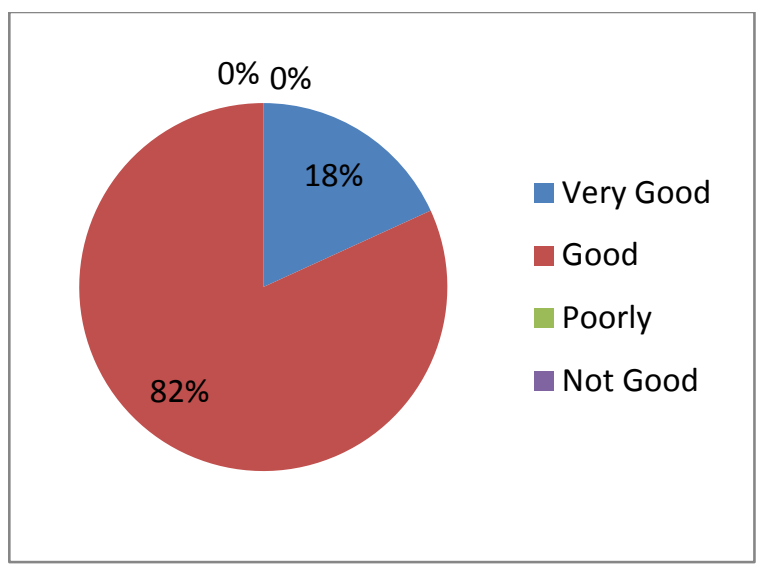

People who live in disaster-prone areas need to have adequate knowledge about disasters that are prone to occur in the area where they live. Disaster knowledge owned by the community needs to be the main concern of stakeholders to improve community preparedness. Knowledge of landslide risk in this study uses the parameters of the availability of information about hazards, mitigation actions, and knowledge of landslides possessed (Rañeses et al., 2018).

Based on the table, the respondent's knowledge of disaster risk is included in the good category with a score of $78.41 \%, 82 \%$ of respondents are in the good category and $18 \%$ are very good.

\section{Experience Facing Disaster}

Based on Havwina (2016), the experience of dealing with disasters can be identified through several indicators, including the experience of a person being directly affected by a disaster, the memory of a disaster, the presence of family members who are victims, residing in disaster-prone areas. The parameters of the experience of landslides in this study were (1) having experienced landslides directly, (2) clearly remembering landslide events, (3) experiencing losses due to landslides, (4) learning from landslides.

Tabel 1.3 Experience Facing Disaster

\begin{tabular}{|c|c|c|c|}
\hline $\mathrm{R}$ & Score & DP (\%) & Category \\
\hline $\mathrm{R} 1$ & 14 & 70 & Good \\
\hline $\mathrm{R} 2$ & 13 & 65 & Poorly \\
\hline R3 & 13 & 65 & Poorly \\
\hline $\mathrm{R} 4$ & 15 & 75 & Good \\
\hline R5 & 3 & 15 & Not Good \\
\hline R6 & 20 & 100 & Very Good \\
\hline R7 & 10 & 50 & Poorly \\
\hline R8 & 14 & 70 & Good \\
\hline R9 & 16 & 80 & Good \\
\hline R10 & 13 & 65 & Poorly \\
\hline R11 & 14 & 70 & Poorly \\
\hline Rerata & 13,181818 & 65,909091 & Poorly \\
\hline
\end{tabular}

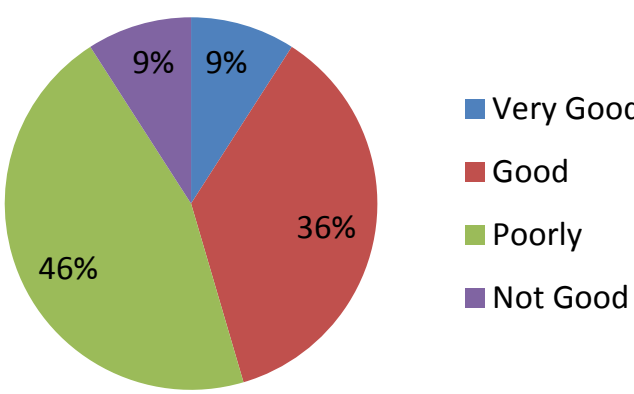


The table shows that $46 \%$ of respondents are in the good category, 36\% are not good, $9 \%$ are very good, and $9 \%$ are not good. The results of the calculation of the average score show that the experience of respondents in dealing with disasters is included in the poor category with a total score of 65.909091.

\section{Attitude of Alertness}

The attitude of vigilance can reduce the number of fatalities caused by disasters (Nasarudin, et al., 2019). Based on Rante (2012) Attitude is one of the most influential variables on preparedness. Most of the respondents in this study had a good attitude of vigilance. This is shown based on the results of the descriptive percentage calculation in table 1.4 below.

Tabel 1.4 Attitude of Alertness

\begin{tabular}{|l|l|l|l|}
\hline R & Score & DP (\%) & Category \\
\hline R1 & 19 & 95 & Very Good \\
\hline R2 & 18 & 90 & Good \\
\hline R3 & 17 & 85 & Good \\
\hline R4 & 15 & 75 & Good \\
\hline R5 & 15 & 75 & Good \\
\hline R6 & 20 & 100 & Very Good \\
\hline R7 & 15 & 75 & Good \\
\hline R8 & 19 & 95 & Very Good \\
\hline R9 & 16 & 80 & Good \\
\hline R10 & 18 & 90 & Good \\
\hline R11 & 15 & 75 & Good \\
\hline Rerata & 17 & 85 & Good \\
\hline
\end{tabular}

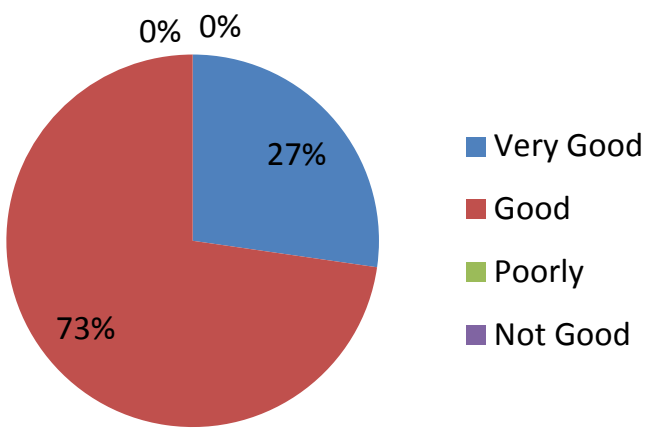

Based on the table $73 \%$ of respondents are in the good category and, $27 \%$ of respondents, are very good. The average calculation shows the results of a descriptive percentage score of $85 \%$, which means that it is included in the good category.

\section{Preparedness Level of the Sepakung Disaster Risk Reduction Forum}

Any pre-disaster activity that aims to develop operational capacity and facilitate effective response when a disaster occurs can be referred to as preparedness (Amri et al., 2020). Disaster preparedness is often linked to other components that make up global civil defense and protection measures (Pinheiro et al., 2021). Based on Rante (2012) preparedness is influenced by knowledge, awareness, and experience in dealing with disasters.

Based on the results of his research, knowledge and attitude of vigilance are the dominant factors that affect preparedness. In this study, the level of preparedness was examined with aspects of knowledge of disaster risk, attitude of vigilance, and understanding of facing disasters. Based on the results of data analysis, it can be seen that the level of preparedness of the Sepakung FPRB is in the good category.

Tabel 1.5 Preparedness Leve

\begin{tabular}{|l|l|l|l|}
\hline \multicolumn{5}{|c}{ Tabel 1.5 Preparedness Level } \\
\hline R & Score & DP (\%) & Category \\
\hline R1 & 66 & 82,5 & Good \\
\hline R3 & 61 & 76,25 & Good \\
\hline R4 & 60 & 75 & Good \\
\hline R5 & 60 & 75 & Good \\
\hline R6 & 48 & 60 & Poorly \\
\hline R7 & 80 & 100 & Very Good \\
\hline R8 & 54 & 67,5 & Poorly \\
\hline R9 & 58 & 72,5 & Good \\
\hline R10 & 64 & 80 & Good \\
\hline R11 & 60 & 82,5 & Good \\
\hline Rerata & 61,545455 & 75 & Good \\
\hline
\end{tabular}

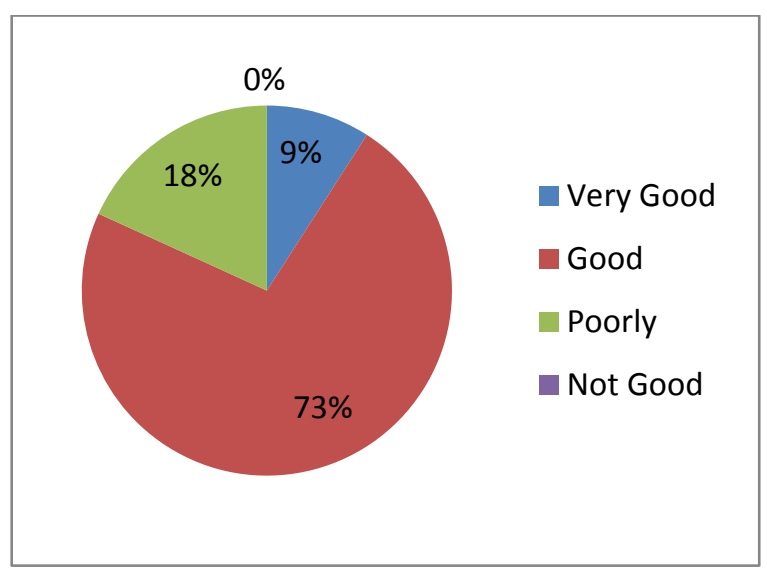


Based on table 1.5, $73 \%$ of respondents are in the good category, $18 \%$ of respondents are not good, and $9 \%$ of respondents are very good. The average calculation shows the descriptive percentage score of $76.93 \%$, which means that the level of preparedness of the Sepakung FPRB is in the good category.

\section{CONCLUSION}

The level of preparedness of the Sepakung FPRB is in the good category. This could be due to ongoing trainings carried out by the village government. This condition also illustrates the concept of an effective Disaster Resilient Village to form FPRB preparedness. However, it should be underlined that there are still $18 \%$ of respondents who are in the poor category so that the government also needs to conduct an evaluation. The evaluation was carried out to find out the cause of the $18 \%$ of FPRB members who had poor preparedness.

\section{ACKNOWLEDGEMENTS}

This study was financed in part by the Semarang State University Postgraduate thesis grant 2021.

\section{Conflict of Interest: None}

\section{Source of Funding: None}

\section{REFERENCES}

1. Aji, A. (2015). Kesiapsiagaan Masyarakat dalam Menghadapi Bencana Banjir Bandang di Kecamatan Welahan Kabupaten Jepara. Indonesian Journal of Conservation, 04(1), $\quad$ 1-8. https://journal.unnes.ac.id/nju/index.php/ijc/ article/view/5152

2. Alkema, D., Kerle, N., \& Kingma, N. C. (2011). Multi-hazard risk assessment (2011th ed.). United Nations University ITC School on Disaster Geo- information Management (UNU-ITC DGIM). http://www.researchgate.net/profile/CJ_Wes ten/publication/259677265_Distance_educat ion_course_on_spatial_multi-

hazard_risk_assessment_using_Open_Sourc e_software/file/72e7e52fd26ee4a965.pdf
3. Amri, I., Ansariadi, Amiruddin, R., Palutturi, S., Mallongi, A., Nur, R., \& Sari, N. E. (2020). The influence of disaster counseling with animation video on preparednes students in elementary school in Palu. Medico-Legal Update, 20(1), 13021306.

https://doi.org/10.37506/v20/il/2020/mlu/19 4482

4. Chae, B. G., Park, H. J., Catani, F., Simoni, A., \& Berti, M. (2017). Landslide prediction, monitoring and early warning: a concise review of state-of-the-art. Geosciences Journal, 21(6), 1033-1070. https://doi.org/10.1007/s12303-017-0034-4

5. Dana, S., Joisangaji, I., \& Mulyaningsih, S. (2017). Studi Fasies Vulkanik Gunung Api Pencu Berdasarkan Pendekatan Stratigrafi, Daerah Banyuasin, Kecamatan Loano, Kabupaten Purworejo, Jawa Tengah. Seminar Nasional Kebumian Ke 10, 10, 1423-1434.

https://repository.ugm.ac.id/274258/1/PVK05.pdf

6. Farhi, Z., Sudibyakto, \& Hadmoko, D. S. (2012). Tingkat Kerentanan Dan Indeks Kesiapsiagaan Masyarakat Terhadap Bencana Tanah Longsor Di Kecamatan Bantarkawung Kabupaten Brebes. Majalah Geografi Indonesia, 26(1), 80-97. https://doi.org/10.22146/mgi.13406

7. Hasnawir. (2012). Intensitas Curah Hujan Memicu Tanah Longsor Dangkal di Sulawesi Selatan. 1(1), 62-73. https://media.neliti.com/media/publications/ 123118-ID-intensitas-curah-hujan-memicutanah-long.pdf

8. Mariana, A., Rahayu, U., Ardiansyah, A. N., \& Nuraeni, N. S. (2019). Wilayah kerawanan longsor di kecamatan pamijahan kabupaten bogor 1,2,3. 19(April), 1-8. https://doi.org/https://doi.org/10.17509/gea. v19i1.13862.g9938

9. Naryanto, H. S. (2011). Analisis Resiko Bencana Tanah Longsor di Kabupaten Karanganyar, Provinsi Jawa Tengah. Jurnal Penanggulangan Bencana, 4(1), 21-32. https:/media.neliti.com/media/publications/ 132656-ID-analisis-kondisi-bawahpermukaan-dan-ris.pdf

10. Park, J., Seager, T. P., Rao, P. S. C., Convertino, M., \& I. Linkov. (2013). Integrating risk and resilience approaches to catastrophe management in engineering systems,. Risk Analysis, 33(3), 356-367. 
https://www.researchgate.net/publication/23 0831578

11. Pinheiro, E. G., Garcias, C. M., \& Ferentz, L. (2021). Disaster Preparedness Indicators. Comunidades e Territórios, 2(1), 105-119. https://doi.org/10.15847/cct.20450

12. Ramadhan, N., Prameswari, M., \& Harijoko, A. (2014). Evaluasi Kondisi Geologi dan Geokimia Potensi Panasbumi Guungapi Telomoyo. Prosiding Seminar Nasional Kebumian Ke-7, 447-458. https://repository.ugm.ac.id/135149/1/447458 M2P-05.pdf

13. Rañeses, M. K., Chang-Richards, A., Richards, J., \& Bubb, J. (2018). Measuring the level of disaster preparedness in Auckland. Procedia Engineering, 212(2017), 419-426. https://doi.org/10.1016/j.proeng.2018.01.05 4

14. Rante, A., Mantu, F. N., \& Patellongi, I. (2012). Tingkat Kesiapsiagaan Rumah Tangga Menghadapi Bencana Alam Tanah Lonsor di Kelurahan Battang Barat Kecamatan Wara Barat Kota Palopo Tahun 2012.

15. Ritohardoyo, S. (2016). Strategi Penghidupan Masyarakat Korban Bencana Tanah Longsor di Kabupaten Banjarnegara. Putrawidya, 17(3), 119-139.

16. Scherzer, S., Lujala, P., \& Rød, J. K. (2019). A community resilience index for Norway: An adaptation of the Baseline Resilience Indicators for Communities (BRIC).
International Journal of Disaster Risk Reduction, 36(October 2018), 101107. https://doi.org/10.1016/j.ijdrr.2019.101107

17. Sriyono, A. (2012). Identifikasi Kawasan Rawan Bencana Longsor Kecamatan Banyubiru , Kabupaten Semarang [Universitas Negeri Semarang]. https://lib.unnes.ac.id/19959/1/3250407028. pdf

18. Sugiyono. (2017). Metode Penelitian Kuantitatif, Kualitatif, dan R\&D. Alfabeta, CV.

19. Suharini, E. dan A. P. (2009). Geomorfologi: Gaya, Proses, dan Bentuk Lahan (D. L. Setyowati (ed.)). Widya Karya.

20. Vasudevan, N., \& Ramanathan, K. (2016). Geological factors contributing to landslides: Case studies of a few landslides in different regions of India. IOP Conference Series: Earth and Environmental Science, 30(1), 1-6. https://doi.org/10.1088/17551315/30/1/012011

How to cite this article: Anugrahanto YD, Setyowati DL, Suharini E. Preparedness of the Sepakung village disaster risk reduction forum in facing landslide disasters. International Journal of Research and Review. 2021; 8(11): 89-95. DOI: https://doi.org/10.52403/ijrr. 20211111 